\title{
EFFECT OF CARIOGENIC FOOD INTAKE ON SALIVARY pH IN CHILDREN (PENGARUH KONSUMSI MAKANAN KARIOGENIK TERHADAP PH SALIVA PADA USIA ANAK)
}

Henri Hartman $^{1 *}$, Rhabiah El Fithriyah ${ }^{1}$, Badi Soerachman ${ }^{2}$, Sarah Aulia Rahmah $^{1}$

${ }^{1 *}$ Department of Pediatric Dentistry, Faculty of Dentistry, Universitas Jenderal Achmad Yani, Cimahi, 40285, Indonesia

${ }^{2}$ Department of Conservative Dentistry, Faculty of Dentistry, Universitas Jenderal Achmad Yani, Cimahi, 40285, Indonesia

*Corresponding author

Henri.hartman@1ecture.unjani.ac.id

Doi:

10.54052/jhds.v1n3.p275288

Article History

Received:21/12/2021

Accepted: $31 / 12 / 2021$

\begin{abstract}
All ages, especially children, favor cariogenic foods. Cariogenic foods are foods that contain fermented carbohydrates, mainly sucrose. Microorganisms are attached to the tooth surface can ferment various types of carbohydrates, becoming acidic and causing a decrease in salivary $\mathrm{pH}$ until it reaches a critical point in salivary $\mathrm{pH}$ followed by dental caries in the future. Saliva is one of the factors that cause dental caries. This study aimed to determine the effect of cariogenic food intake on changes in children's pH salivary. This research was conducted with a literature study as a reference and analyzed the findings obtained. The sample used was nine pieces of literature consisting of 19 cariogenic foods. This study showed a statistically significant result $(p<0.05)$ in a change of salivary $\mathrm{pH}$ value before cariogenic food and after cariogenic food intake. Around $42.53 \%$ of children experienced a decrease in salivary $\mathrm{pH}$ more significant than the average after cariogenic foods intake, and $57.47 \%$ of children experienced a reduction in $\mathrm{pH}$ salivary. There are $49.74 \%$ of children have $\mathrm{pH}$ salivary lower than its average
\end{abstract}


value, which could be lead to demineralization of enamel.

Keywords: cariogenic food; dental caries; $\mathrm{pH}$

\begin{abstract}
ABSTRAK
Semua usia, terutama anak-anak, menyukai makanan kariogenik. Makanan kariogenik adalah makanan yang mengandung karbohidrat hasil fermentasi, terutama sukrosa. Mikroorganisme yang menempel pada permukaan gigi dapat memfermentasikan berbagai jenis karbohidrat, menjadi asam dan menyebabkan penurunan $\mathrm{pH}$ saliva hingga mencapai titik kritis pH saliva yang diikuti dengan karies gigi di kemudian hari. Air liur merupakan salah satu faktor penyebab terjadinya karies gigi. Penelitian ini bertujuan untuk mengetahui pengaruh asupan makanan kariogenik terhadap perubahan pH saliva anak. Penelitian ini dilakukan dengan studi kepustakaan sebagai acuan dan menganalisis temuan yang diperoleh. Sampel yang digunakan adalah sembilan buah literatur yang terdiri dari 19 makanan kariogenik. Penelitian ini menunjukkan hasil yang signifikan secara statistik $(p<0,05)$ pada perubahan nilai $p H$ saliva sebelum makanan kariogenik dan setelah asupan makanan kariogenik. Sekitar 42,53\% anak-anak mengalami penurunan pH saliva yang lebih signifikan dari rata-rata setelah asupan makanan kariogenik, dan 57,47\% anak-anak mengalami penurunan $\mathrm{pH}$ saliva. Terdapat 49,74\% anak yang memiliki pH saliva lebih rendah dari nilai rata-rata, yang dapat menyebabkan demineralisasi email.
\end{abstract}

Kata kunci: karies gigi; makanan kariogenik; $p H$

\section{INTRODUCTION}

Humans as need food intake to fulfill their needs. Various types of food are available in the community, but all ages, especially children, prefer sweet foods. Sweet foods contain sucrose, so it is cariogenic to the teeth. Many cariogenic foods are found sweet, soft, crushed, and attached quickly to the teeth, such as candy, ice cream, biscuits, chocolate, confectionery, and others. This kind of food has a sweet and delicious taste, and the price is relatively low, easy to get, and is sold in various shapes and colors that are varied 
and attractive for the children. Sweet foods are easily attached to the tooth surface if they are not cleaned properly and will be metabolized by bacteria to form acids that damage the tooth structure if left for a long time. ${ }^{1-6}$

The foods can affect teeth and mouth health, especially the condition of saliva in the oral cavity. After consuming carbohydrates, the salivary $\mathrm{pH}$ decrease in 1-3 minutes until the value is less than five because bacteria and form acids ferment carbohydrates. Meanwhile, cariogenic food will be neutralized by saliva after 60 minutes. If the child often eats cariogenic foods, the oral cavity remains in an acidic atmosphere. It causes a demineralization process because the saliva $\mathrm{pH}$ is below the normal salivary ( $\mathrm{pH}$ value between 6.2-7.6). Microorganisms attached to the tooth surface can metabolize carbohydrates into acids and cause a decrease in salivary $\mathrm{pH}$ until it reaches a critical salivary $\mathrm{pH}$. The atmosphere of the oral cavity $(\mathrm{pH})$ in an acidic state will support the growth of acidogenic bacteria in the oral cavity, such as Streptococcus mutants and Lactobacillus. ${ }^{6-10}$

Based on the modified Keyes Jordan diagram, saliva is one of the primary factors that can influence the occurrence of caries. Caries is the demineralization or dissolution of the organic matrix in the teeth by bacteria that produce acid. The caries process begins with the fermentation of carbohydrates by microorganisms into acid, which causes a decrease in salivary $\mathrm{pH}$ to reach a critical $\mathrm{pH}$ of less than 5.5 on the enamel surface. The hydroxyapatite ion in the enamel dissolves, and a demineralization process occurs. Caries is the most significant dental and oral health problem in Indonesia. Based on the Basic Health Research (Riskesdas) results in 2018, it was found that the prevalence of caries in Indonesia reached $45.3 \%$. While the majority of caries in children based on the age group 3-4 years is $81.1 \%$, aged $4-9$ years is $92.6 \%$, and aged $10-14$ years is $73.4 \%$. Along with the high level of cariogenic food consumption in children and the high level of caries in children in Indonesia, where salivary $\mathrm{pH}$ is one of the factors for caries occurrence. This study was conducted to know the effect of cariogenic food consumption on changes in salivary $\mathrm{pH}$ in children. ${ }^{11-13}$

\section{METHOD}

The research was conducted from September 2020 to December 2020 using the required software, journals, and databases, summarize with these sequences.

Research design: The research was descriptive to know the effect of consuming cariogenic foods on the $\mathrm{pH}$ value of saliva in children. The research was done by 
conducting a literature study on several libraries used as a reference and analyzing the findings obtained.

Research object: Using nine pieces of literature related to the effect of cariogenic food consumption on salivary $\mathrm{pH}$ in children with 19 types of cariogenic food.

Method of sampling: A library search was conducted using the google search engine on the internet with the keywords: cariogenic foods, sweet foods, sucrose, saliva, and salivary $\mathrm{pH}$. The database was taken from reputable articles from Google Scholar, PubMed, Researchgate, science direct, WHO, and the Indonesian Ministry of Health.

Research procedure: This research procedure consisted of preparation, implementation, and report generation stages. In the preparatory phase, the researchers search for various kinds of literature according to the theme using Google search engine on the internet with the keywords: cariogenic foods, sweet foods, sucrose, saliva, and salivary $\mathrm{pH}$. The research was carried out by analyzing the literature according to the specified theme. The results are written in a report, and the synthesis was made in the form of a synthesis matrix. It was based on the elements of the same topic and draws conclusions based on the findings in the literature.

Data analysis: The data obtained from the research and synthesis of literature according to the theme were descriptive and statistically checked.

\section{RESULT}

The literature study was conducted by analyzing nine pieces of literature. Research undertaken by Asridiana in 2019 used the cariogenic type of chocolate with a sample of 40 children aged 7-12 years. Salivary $\mathrm{pH}$ measurement showed that the average salivary $\mathrm{pH}$ value before consuming chocolate was 6.04. The average weight of salivary $\mathrm{pH}$ after consuming chocolate was 5.73. The difference in the average change in salivary $\mathrm{pH}$ before and after consuming chocolate was $0.31 .{ }^{14}$

Jannah et al., in 2016, used a cariogenic food type of $75 \mathrm{gr}$ biscuit, which was chewed for 1 minute with a sample of 40 children aged 7-12 years. Salivary $\mathrm{pH}$ measurement showed that the average salivary $\mathrm{pH}$ value before consuming biscuits was 7.20. The average weight of salivary $\mathrm{pH}$ after consuming biscuits was 7.02. The difference in the average change in salivary $\mathrm{pH}$ before and after consuming biscuits was $0.18 .^{15}$

$$
\text { Marlindayanti in } 2019 \text { used }
$$
cariogenic food types, purple sweet potato biscuits, and wheat biscuits with a sample 
of 2 children aged 10-12 years. The measurement of salivary $\mathrm{pH}$ on the consumption of purple sweet potato biscuits showed that the average salivary $\mathrm{pH}$ value before consuming purple sweet potato biscuits was 9.30. The average weight of salivary $\mathrm{pH}$ after consuming purple sweet potato biscuits was 8.58 . The average difference between changes in salivary $\mathrm{pH}$ before and after consuming purple sweet potato biscuits was 0.72 . The results of the measurement of salivary $\mathrm{pH}$ on the consumption of wheat biscuits showed that the average salivary $\mathrm{pH}$ value before consuming wheat biscuits was 8.23. The average weight of salivary $\mathrm{pH}$ after consuming wheat biscuits was 6.45 . The difference in the average change in salivary $\mathrm{pH}$ before and after consuming wheat biscuits was $1.78 .^{16}$

Rahmawati et al. (2015) used soft drinks with a sample of 63 children aged 89 years. Salivary $\mathrm{pH}$ measurement results obtained the average salivary $\mathrm{pH}$ value before consuming soft drinks was 5.75. The average value of salivary $\mathrm{pH}$ after consuming soft drinks was 4.54. The average difference between changes in salivary $\mathrm{pH}$ before and after consuming soft drinks was $1.21 .{ }^{17}$

Soeryani et al. (2020) used cariogenic food types of chocolate and candy with a sample of 30 children aged $12-13$ years. The measurement of salivary $\mathrm{pH}$ on chocolate consumption showed that the average salivary $\mathrm{pH}$ value before consuming chocolate was 7.38. The average value of salivary $\mathrm{pH}$ after consuming chocolate was 6.71. The average difference between changes in salivary $\mathrm{pH}$ before and after consuming chocolate was 0.67. The measurement of salivary $\mathrm{pH}$ on candy consumption showed that the average salivary $\mathrm{pH}$ value before consuming candy was 7.38. The average value of salivary $\mathrm{pH}$ after consuming sweets is 6.85 . The difference in the average change in salivary $\mathrm{pH}$ before and after consuming sweets was $0.53 .^{18}$

Sousa et al., in 2020, used a cariogenic food type of $20 \%$ sucrose with a sample of 28 children aged 3-5 years. Salivary $\mathrm{pH}$ measurement results showed that the average salivary $\mathrm{pH}$ value before rinsing with a $20 \%$ sucrose solution was 7.67. The average value of salivary $\mathrm{pH}$ after gargling with a $20 \%$ sucrose solution was 7.54. The difference in the average change in salivary $\mathrm{pH}$ before and after rinsing with a $20 \%$ sucrose solution was $0.22 .{ }^{19}$

de Sousa et al. in (2020) used cariogenic food types of $20 \%$ sucrose, $2 \%$ starch, and 20\% sucrose plus 2\% starter with a sample of 27 children aged 4-5 years. The measurement of salivary $\mathrm{pH}$ on gargling with a 20\% sucrose solution 
obtained the average $\mathrm{pH}$ value of saliva before rinsing with a $20 \%$ sucrose solution was 7.68. The average value of salivary $\mathrm{pH}$ after gargling with $20 \%$ sucrose solution was 7.36. The average difference between changes in salivary $\mathrm{pH}$ before and after rinsing with a $20 \%$ sucrose solution was 0.32. The measurement of salivary $\mathrm{pH}$ against gargling with a $2 \%$ Starch solution obtained the average value of salivary $\mathrm{pH}$ before rinsing with a $2 \%$ Starch solution was 7.66. The average value of salivary $\mathrm{pH}$ after gargling with $2 \%$ Starch solution was 7.53. The average change in salivary $\mathrm{pH}$ before and after gargling with a 2\% Starch solution was 0.13 . The results of the measurement of salivary $\mathrm{pH}$ on gargling with a resolution of $20 \%$ sucrose plus $2 \%$ starter obtained the average value of salivary $\mathrm{pH}$ before rinsing with a solution of $20 \%$ sucrose plus $2 \%$ starter was 7.69 . The average value of salivary $\mathrm{pH}$ after gargling with a resolution of $20 \%$ sucrose plus $2 \%$ starter was 7.22. The difference in the average change in salivary $\mathrm{pH}$ before and after gargling with a solution of $20 \%$ sucrose plus $2 \%$ starter was $0.47 .{ }^{20}$

Kumar et al. (2019) used cariogenic foods such as oats biscuits, saltine crackers, sugar biscuits, cream biscuits, and chocolate biscuits with a sample of 50 children aged 10-15 years. The results of salivary $\mathrm{pH}$ on the consumption of oats biscuits showed that the average salivary $\mathrm{pH}$ value before consuming oats biscuits was 7.48. The average value of salivary $\mathrm{pH}$ after consuming oats biscuits was 7.07. The average difference between changes in salivary $\mathrm{pH}$ before and after consuming oats biscuits was 0.41 . The results of salivary $\mathrm{pH}$ on the consumption of salted biscuits showed that the average salivary $\mathrm{pH}$ value before consuming salted biscuits was 7.59. The average value of salivary $\mathrm{pH}$ after consuming saltine crackers was 7.08. The average change in salivary $\mathrm{pH}$ before and after consuming saltine biscuits was 0.51 . The results of salivary $\mathrm{pH}$ on the consumption of sugar biscuits showed that the average salivary $\mathrm{pH}$ value before consuming sugar biscuits was 7.22. The average value of salivary $\mathrm{pH}$ after consuming sugar biscuits was 6.32. The average difference between changes in salivary $\mathrm{pH}$ before and after consuming sugar biscuits was 0.90 . The results of salivary $\mathrm{pH}$ on the consumption of cream biscuits showed that the average salivary $\mathrm{pH}$ value before consuming cream biscuits was 7.42 . The average value of salivary $\mathrm{pH}$ after consuming cream biscuits was 6.63. The average difference between changes in salivary $\mathrm{pH}$ before and after consuming cream biscuits was 0.79 . The results of salivary $\mathrm{pH}$ on chocolate biscuit consumption showed that the average 
salivary $\mathrm{pH}$ value before consuming chocolate biscuits was 7.54. The average value of salivary $\mathrm{pH}$ after consuming chocolate biscuits was 6.66 . The difference in the average change in salivary $\mathrm{pH}$ before and after consuming chocolate biscuits was $0.88 .^{21}$

Janani (2018) used milk chocolate, white chocolate, and dark chocolate cariogenic foods with a sample of 90 children aged 8-12 years. The results of salivary $\mathrm{pH}$ on milk chocolate consumption showed that the average salivary $\mathrm{pH}$ value before consuming milk chocolate was 6.17. The average value of salivary $\mathrm{pH}$ after consuming milk chocolate was 5.28. The average difference between changes in salivary $\mathrm{pH}$ before and after consuming milk chocolate was 0.89 . The results of salivary $\mathrm{pH}$ on the consumption of white chocolate showed that the average salivary $\mathrm{pH}$ value before consuming white chocolate was 6.51 . The average value of salivary $\mathrm{pH}$ after consuming white chocolate was 5.76. The average difference between changes in salivary $\mathrm{pH}$ before and after consuming white chocolate was 0.75 . The results of salivary $\mathrm{pH}$ on dark chocolate consumption showed that the average salivary $\mathrm{pH}$ value before consuming dark chocolate was 6.52 . The average value of salivary $\mathrm{pH}$ after consuming dark chocolate was 6.06 . The average difference between changes in salivary $\mathrm{pH}$ before and after consuming dark chocolate was $0.46 .^{21}$

Based on the findings in the literature above regarding the consumption of cariogenic foods on changes in salivary $\mathrm{pH}$, the following results were obtained:

Table 1. Changes in salivary $\mathrm{pH}$

\begin{tabular}{|c|c|c|c|c|c|}
\hline$a$ & 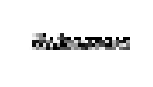 & 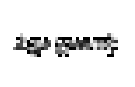 & 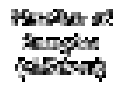 & itfar & 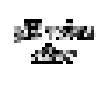 \\
\hline 5 & $\sum_{\text {havod }}^{\text {And }}$ & 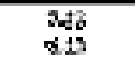 & 36 & 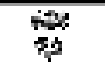 & $\begin{array}{l}\text { Sal } \\
\text { tet: }\end{array}$ \\
\hline \multirow[t]{2}{*}{$\$$} & 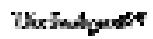 & Tas & 80 & is & $\therefore x$ \\
\hline & & & 26 & $a, x$ & $6 \pi$ \\
\hline 4 & Aztrasat: & ast & to & $\operatorname{lit}$ & 408 \\
\hline $\mathrm{i}$ & Honse & A & 10 & 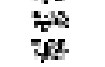 & 象 \\
\hline$\ell$ & 마보요 & $\$ 4$ & 25 & 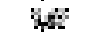 & 20 \\
\hline \multirow[t]{3}{*}{5} & 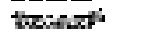 & 2,2 & 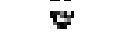 & $\forall$ 政 & $x \rightarrow 0$ \\
\hline & & & & ass & $x, y$ \\
\hline & & & & 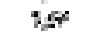 & $x$ \\
\hline \multirow[t]{4}{*}{8} & $\operatorname{sen} x^{\circ}$ & Fas & 舟 & 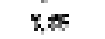 & $7 \%$ \\
\hline & & & 25 & 20 & ses \\
\hline & & & 13 & 52 & $\operatorname{sex}$ \\
\hline & & & 10 & 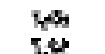 & ${ }^{2}$ \\
\hline \multirow[t]{4}{*}{ R } & a土st & E्या & $\infty$ & 36 & 60 \\
\hline & & 195 & 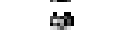 & 5,2 & $\frac{\pi}{2} \pi$ \\
\hline & & $20 ;$ & 就 & si & fot \\
\hline & & $68 \mathrm{xs}$ & & $12 x$ & ans \\
\hline
\end{tabular}

Table 2. Percentage of decrease in saliva $\mathrm{pH}$

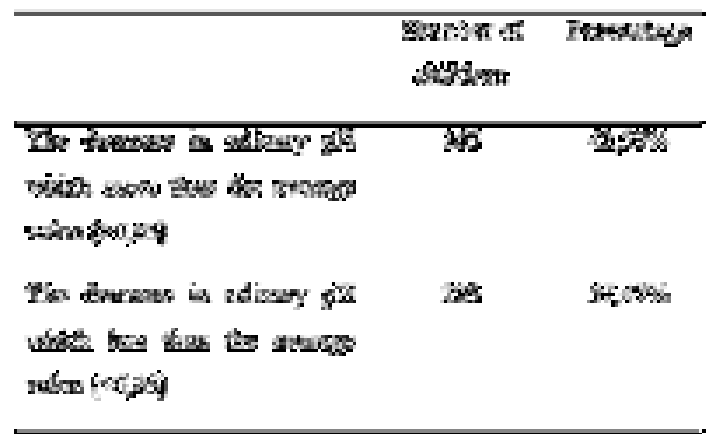


Table 3. Percentage with normal $\mathrm{pH}$ value

\begin{tabular}{|c|c|c|}
\hline & 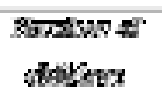 & 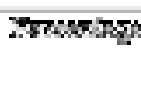 \\
\hline 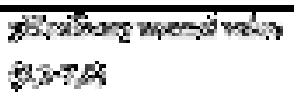 & ngs & $58 \mathrm{~s}$ \\
\hline 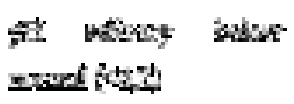 & $\mathrm{res}$ & 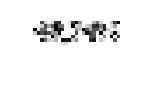 \\
\hline
\end{tabular}

\section{DISCUSSION}

Based on Table 1, the results of the literature study, the effect of cariogenic food consumption on salivary $\mathrm{pH}$ in children that have been carried out show that salivary $\mathrm{pH}$ decreased by 0.66 between before and after consuming cariogenic foods based on the calculation of the average change in salivary $\mathrm{pH}$ value. The average salivary $\mathrm{pH}$ value before consuming cariogenic food was 7.31 and after consuming cariogenic food was 6.65 . In Table 1, the result was listed for the t-test and showed a significant effect statistically $(p<0.05)$. The total number of children who were respondents in the relevant literature was 388. The percentage of children who experienced changes in salivary $\mathrm{pH}$ after consuming cariogenic foods will be explained in Table 2.

The highest salivary $\mathrm{pH}$ value before consuming cariogenic food was found by Marlindayanti (2019) with a quasiexperimental research method, a sample of 20 children aged 10-12 years with a value of 9.30, and the type of cariogenic food used was a wheat biscuit. The lowest salivary $\mathrm{pH}$ value before consuming cariogenic food was found in a study conducted by Ida Rahmawati et al. (2015) with experimental research methods pretest and posttest group, a sample of 63 children aged 8-9 years with a value of 5.75 and the type of cariogenic food used are soft drinks. ${ }^{16,17}$

The highest $\mathrm{pH}$ value of saliva after consuming cariogenic food was found in a study conducted by Marlindayanti (2019) with a quasi-experimental research method, a sample of 20 children aged 10-12 years with a value of 8.58 and the type of cariogenic food used was a wheat biscuit. The lowest salivary $\mathrm{pH}$ value after consuming cariogenic foods was found in a study conducted by Rahmawati et al. (2015) with experimental research methods pretest and posttest group, a sample of 63 children aged 8-9 years with a value of 4.54 and the type of cariogenic food used is soft drinks. ${ }^{16,17}$

The highest decrease in salivary $\mathrm{pH}$ was found in a study conducted by Marlindayanti (2019) with a quasiexperimental research method and a sample of 20 children aged $10-12$ years with a salivary $\mathrm{pH}$ value of 8.23 before consuming cariogenic food and 6.45 after consuming cariogenic food. The decrease in salivary $\mathrm{pH}$ that occurred in this library was 1.78. The type of cariogenic food used in this 
study was a wheat biscuit. ${ }^{16}$

The lowest decrease in salivary $\mathrm{pH}$ was found in a study conducted by de Sousa et al. (2020) with experimental research methods with pretest and posttest groups and a sample of 27 children aged 2-5 years with a salivary $\mathrm{pH}$ value before consuming cariogenic foods of 7.66 and after consuming cariogenic food by 7.53 . The decrease in salivary $\mathrm{pH}$ that occurred in this library was 0.13 . The type of cariogenic food used in this study was $2 \%$ starch. $^{20}$

Based on Table 2, it was found that as many as 165 children, or $42,53 \%$ experienced a decrease in salivary $\mathrm{pH}$ more than the average after consuming cariogenic foods, and 223 children or $57,47 \%$ of children experienced a reduction of salivary $\mathrm{pH}$ below the average after consuming cariogenic foods.

Based on the literature study results above, a decrease in salivary $\mathrm{pH}$ can occur shortly after exposure to carbohydrates. The decline in salivary $\mathrm{pH}$ can be different for each individual, influenced by the individual's oral cavity health. Pachori et al. (2018) a decrease in salivary $\mathrm{pH}$ after consuming cariogenic foods can occur because cariogenic foods contain the most suitable carbohydrates for acid production by bacteria in plaque, such as sucrose, glucose, fructose, maltose, and others. Sugars have small molecules that easily diffuse into the plaque and are quickly broken down by bacteria into acids. Carbohydrates in liquid form have less effect than solid carbohydrates. It is because carbohydrates in the form of liquids are lost more quickly from the oral cavity, solid carbohydrates allow them to remain in the oral cavity and are more difficult to clean, especially if the food is quite sticky. ${ }^{22-24}$

Based on Table 3, shows 195 children or $50,25 \%$ experienced a decrease in salivary $\mathrm{pH}$ but it was still within the normal range of salivary $\mathrm{pH}$ after consuming cariogenic foods. Several 193 children or $49,74 \%$ experienced a decrease in salivary $\mathrm{pH}$ below the normal range of salivary $\mathrm{pH}$ after consuming cariogenic foods.

A decrease in salivary $\mathrm{pH}$ can cause demineralization when reaches a critical $\mathrm{pH}$ below 5.5. In acidic saliva $\mathrm{pH}$ conditions, Streptococcus mutans grow in the oral cavity and increase their metabolism. After consuming cariogenic food, Streptococcus mutans ferment carbohydrates into lactic acid assisted by the GTF enzyme. It synthesizes carbohydrates into glucose as an energy source and forms glucan as a colonization site. Salivary $\mathrm{pH}$ takes 60 minutes to be neutralized back to its initial value before consuming cariogenic food. If a person tends to have a high frequency of consumption of cariogenic foods, the salivary $\mathrm{pH}$ will continue to be acidic and 
reach a critical $\mathrm{pH}$ so that demineralization occurs which if not balanced with remineralization can cause caries. ${ }^{23-26}$

The state of salivary $\mathrm{pH}$ is influenced by several factors, including the food or drink consumed, the buffering function of saliva, the speed of salivary flow, microorganisms found in the oral cavity, and oral health conditions. Food and drink consumption can cause changes in salivary $\mathrm{pH}$ directly. The more bicarbonate ions in the saliva, the better the saliva buffer function. The ability of saliva to buffer can neutralize acids produced by cariogenic microorganisms and function for antibacterial activity. The ability of saliva to buffer acid is very important to keep the $\mathrm{pH}$ value above the critical $\mathrm{pH}$. Thereby protecting teeth from demineralization is very important. The type and number of microorganisms in the oral cavity can affect the $\mathrm{pH}$ of saliva. Individuals with poor $\mathrm{OH}$ microorganisms suffer more microorganisms that affect carbohydrate metabolism to produce acid. The speed of salivary flow affects the quantity of saliva secreted. The more the quantity of saliva, the more bicarbonate ions in the saliva. With age, the salivary secretion decreases because the parenchyma in the glands and replaced by connective tissue and fat tissue.

A person's social and economic status determines attitudes and habits in maintaining oral hygiene and health. In addition to the theoretical factors above, this study also obtained research factors from the literature used. The measurement time and sampling method can affect the results obtained. ${ }^{23,27-30}$

\section{CONCLUSION}

Based on the results, we found that there was a significant result statistically $(\mathrm{p}<0.05)$ changing value between $\mathrm{pH}$ salivary before and after consuming cariogenic food. It showed that salivary $\mathrm{pH}$ decreased by 0.66 on average, $57.47 \%$ of children experienced a decrease in salivary $\mathrm{pH}$ exceeding the average. Around 49,74\% of children have $\mathrm{pH}$ saliva lower than it's normal which could lead to demineralization of enamel. From our viewpoint, each food will have a different effect on salivary $\mathrm{pH}$, depending on the types and ingredients.

\section{CONFLICT OF INTEREST}

We hereby declare that there is no conflict of interest in the scientific articles that we wrote.

\section{ACKNOWLEDGEMENT}

Our gratitude goes to the Faculty of Dentistry Unjani staff who have helped with this draft papers. 


\section{REFERENCES}

1. Kathleen L SE-S. Nutrition and dietetics. Krause's, food and nutrition therapy. 2011: 865-872.

2. Indah IS. Data konsumsi makanan penduduk Indonesia. Pusat Data dan Informasi Kementrian Kesehatan Indonesia. 2016.

3. Aprilyana P, Astuti E, Prasetya MA, Sukrama IDM, Studi P, Dokter P, et al. Hubungan tingkat konsumsi karbohidrat dengan kejadian karies pada anak taman kanak-kanak tunas wijaya, Desa Tonja , Kecamatan Denpasar Utara. Bali Dent J. 2017; 1(2): 40-6.

4. Rehena Z. Hubungan jenis dan frekuensi konsumsi makanan kariogenik dengan kejadian karies gigi pada anak SDN 5 Waai kabupaten Maluku Tengah. J Kesehat UKIM. 2019; 1(April): 90-6.

5. Pertiwi I, Rahaswanti LWA, Sutadarma IWG. Gambaran kejadian karies dan konsumsi makanan kariogenik pada anak usia 10-12 tahun di Sekolah Dasar Negeri 3 Batur. Bali Dent J. 2018; 2(2): 88-94.

6. Lestari NWAD, Fitriana LB. Usia dan frekuensi mengkonsumsi makanan kariogenik berhubungan dengan kejadian karies gigi anak. J Holist Nurs Sci. 2018; 5(2): 72-81.

7. Tri E, Subaktilah Y, Elisanti AD. Analysis of cariogenic food consumption towards children of children in primary schools. J Keseharan Gigi. 2020; 8(1): 10-5.

8. Silvia C, Y GP, Luthfiasari D. Hubungan antara konsumsi makanan kariogenik dan frekuensi gosok gigi dengan kejadian karies gigi pada anak usia 3-5 tahun. J Kedokt Gigi Anak. 2017; 39(1): $1-4$.

9. Kumar N, Anupama Nayak P, Natarajan S, Mahabala KY, Rao A. Effect of different commercially available biscuits on salivary ph, flow rate and oral clearance rate among children. World J Dent. 2019; 10(1): 35-40.

10. Rawung F, Wuisan J, Leman MA. Pengaruh obat kumur beralkohol terhadap laju aliran saliva dan $\mathrm{pH}$ saliva. e-GIGI. 2017; 5(2).

11. Aprinta IKP, Prasetya MA, Wirawan IMA. Hubungan frekuensi menyikat gigi dan konsumsi makanan kariogenik dengan kejadian karies gigi molar pertama permanen pada anak sekolah dasar usia 8-12 tahun di Desa Pertima, Karangasem, Bali. Bali Dent J. 2018; 2(1): 1-8.

12. Andre V, Lee W, Walter R. The art and science of operative dentistry. 2019; 54: 611 .

13. Kurniawan R, Widiantini W, Mulya D. Pusat data dan informasi kesehatan gigi. Kementrian Kesehat RI. 2019. 
14. Asridiana, Thioritz E. Pengaruh mengonsumsi makanan manis dan lengket terhadap $\mathrm{pH}$ saliva pada murid SDN Mamajang Makassar. Media Kesehat Gigi. 2019; 18(1): 34-40.

15. Jannah M, Hidayati, Afriwardi. Perbedaan $\mathrm{pH}$ saliva antara berkumur dan tanpa berkumur air putih setelah mengunyah makanan. Andalas Dent J. 2016: 67-77.

16. Marlindayati, Keperawatan J, Poltekkes G, Palembang K. Efek konsumsi biskuit ubi ungu terhadap saliva dalam upaya pencegahan karies. J Kesehat Gigi dan Mulut. 2019; 1(1): 1722.

17. Rahmawati I, Said F, Hidayati S. Perbedaan $\mathrm{pH}$ saliva sebelum dan sesudah mengonsumsi minuman ringan. J Skala Kesehat. 2015; 6(1): 11.

18. Soeryani RW, Nurrochman A, Nurwanti W, Khoirunisa ST. Perubahan $\mathrm{pH}$ saliva sebelum dan sesudah mengonsumsi makanan kariogenik. JDHT J Denatal Hyg Ther. 2020; 1(18): 31-4.

19. de Sousa ET, Lima-Holanda AT, Nobre-dos-Santos M. Changes in the salivary electrolytic dynamic after sucrose exposure in children with early childhood caries. Sci Rep. 2020; 10(1): $1-8$.

20. de Sousa ET, Lima-Holanda AT,
Sales LS, Nobre-dos-Santos M. Combined effect of starch and sucrose on carbonic anhydrase VI activity in saliva and biofilm of children with early childhood caries. Exposure to starch and sucrose alters carbonic anhydrase VI activity in saliva and biofilm. Clin Oral Investig. 2020.

21. Dr.Janani RG. Effect of custommade probiotic chocolates on streptococcus mutans, plaque $\mathrm{pH}$, salivary $\mathrm{pH}$ and buffering capacity in children- a randomized controlled trial. Inst Dent Sci Res. 2018.

22. Pachori A, Kambalimath H, Maran S, Niranjan B, Bhambhani G, Malhotra G. Changes in salivary $\mathrm{pH}$ after intake of different eatables and beverages evaluation of changes in salivary $\mathrm{pH}$ after intake of different eatables and beverages in children at different time intervals. Int J Clin Pediatr Dent. 2018; 11(3): 177-82.

23. Bhola M, Palta S. Cariogenicity of various food products and its oral clearance. Int J Med Biomed Stud. 2020; 4(6): 1-5.

24. Maryama VQ, Suyatmi D, Almujadi. Gambaran pH saliva pada siswa-siswi Madrasah Tsanawiah di Tegalarum Klaten. J Oral Heal Care. 2017.

25. Maharani RS, Siswomiharjdo W, 
Sunarintyas S. Pengaruh variasi $\mathrm{pH}$ saliva terhadap perlekatan Streptococcus mutans pada resin komposit nanofil. J Mater Kedokt Gigi. 2017; 6(2): 51.

26. Sukma CE, Elyani H, Yahya A. Pengaruh menyikat gigi dengan kombinasi pasta gigi dan siwak (Salvadora persica) terhadap jumlah koloni bakteri anaerob pada saliva dan mukosa gingiva santri Ar-Razi. J Mater Process Technol. 2018; 1(1): 1-8.

27. Khan A, Qureshi B, Qureshi A, Imtiaz Y, Qadeer S. Correlation of salivary characteristics with high risk of dental caries; A clinical investigation. Futur Dent J. 2018; 4(1): 72-5.

28. Hapsari NF, Ismail A, Santoso O. Pengaruh konsumsi keju cheddar 10 gram terhadap $\mathrm{pH}$ saliva. ODONTO Dent J. 2016; 1(1): 34.

29. Tawas SAD, Mintjelungan $\mathrm{CN}$, Pangemanan DHC. Xerostomia pada usia lanjut di Kelurahan Malalayang Satu Timur. e-GIGI. 2018; 6(1):1-4.

30. Meilita Fatmasari, Widodo RA. Hubungan antara tingkat sosial ekonomi dengan indeks karies gigi pelajar SMPN di Kecamatan Banjarmasin Selatan. J Kedokt Gigi. 2017; I(1): 627. 